\title{
Insulin-like Growth Factor I and Insulin-like Growth Factor Binding Protein 3 as Determinants of Blood Hemoglobin Concentration in Healthy Subjects
}

\author{
RAIJA ANTTILA, RITTA KOISTINEN, MARKKU SEPPÄLÄ, HANNU KOISTINEN, AND \\ MARTTI A. SIIMES \\ Children's Hospital and Departments I and II of Obstetrics and Gynecology, Helsinki University \\ Central Hospital, FIN-00290 Helsinki, Finland
} \begin{abstract}
ARS
We studied the serum concentrations of IGF-I, IGF-
binding protein 3 (IGFBP-3), and testosterone in relation to blood $\mathrm{Hb}$ in 60 healthy prepubertal or early pubertal boys twice, with a 9-mo interval. Serum IGF-I and testosterone levels were measured by RIA, and serum IGFBP-3 was measured by monoclonal immunofluorometric assay. Positive correlations were observed between the concentrations of blood $\mathrm{Hb}$ and serum IGF-I at the first examination $(r=0.36, p=0.008)$ and $\mathrm{Hb}$ and IGFBP-3 at both examinations $(r=0.53, p<0.001$, and $r=0.39, p=0.003)$. No association between $\mathrm{Hb}$ and testosterone concentrations was found. Our results show that blood $\mathrm{Hb}$ is positively
\end{abstract}

correlated to serum IGF-I and IGFBP-3 levels, indicating indirectly the involvement of growth hormone in the regulation of physiologic $\mathrm{Hb}$ concentration. Because no association was found between $\mathrm{Hb}$ and testosterone concentrations, this may indicate that the role of androgens in erythropoiesis may be different at different stages of puberty. It is concluded that the IGF system may be involved in the rise of $\mathrm{Hb}$ level during early puberty. (Pediatr Res 36: 745-748, 1994)

IGFBP, IGF-binding protein
IGF-I and IGF-II act as mediators of growth hormone actions and participate in the regulation of cell division, growth, and differentiation (1). The serum concentration of the major IGF-binding protein (IGFBP-3) reflects the total amount of IGF-I and IGF-II in the circulation and the secretion of growth hormone similarly or even better than the serum concentration of IGF-I alone (2). IGF-I has a role in the regulation of the erythropoietic system in vitro and also in vivo (3-9). IGF-I stimulates proliferation of murine and human erythroid progenitor cells in bone marrow culture systems $(4,6)$. The optimum in vitro erythropoiesis appears to depend on several systems, including erythropoietin, stem cell factor, IGF-I, and unidentified factors $(8,9)$.

The stimulatory effect of androgens on erythropoiesis is well documented (10). Thomsen et al. (11) found that the marked rise in blood $\mathrm{Hb}$ concentration takes place during a short period in male puberty coinciding with an

Received December 6, 1993; accepted June 30, 1994

Correspondence: Martti A Siimes, M.D., Associate Professor of Pediatrics, Children's Hospital, University of Helsinki, FIN-00290 Helsinki, Finland.

Supported by grants from the Sigrid Juselius Foundation, the Academy of Finland, the Cancer Society of Finland, the University of Helsinki, Finland, and the Nordisk Insulin Foundation Committee. increasing serum testosterone level. We studied the role of serum concentrations of IGF-I, IGFBP-3, and testosterone in the maintenance of blood $\mathrm{Hb}$ concentration in 60 healthy prepubertal or early pubertal boys twice, with a 9-mo interval. Possibly several regulatory mechanisms of increasing erythropoiesis have different roles at different stages of male puberty.

\section{METHODS}

Subjects. An opportunity to participate in the study was offered to 84 boys of the same secondary school level in three schools near the Children's Hospital, Helsinki. The study was approved by the parents, the school authorities, those responsible for school health care, and the Ethical Committee of the Children's Hospital. Written information about the study was sent to the families. Of the 84 boys, 62 agreed to participate. There were two dropouts, leaving 60 boys for the study. Medical history and physical examination indicated that all the boys were healthy except three who used seasonal medication for asthma. Epilepsy was diagnosed in one boy during the study, and he was given oxicarbamazepine medication. These four boys were included in the study. 
Methods. The study included two examinations with a 9-mo interval. Body weight was always measured on the same platform scale with the boys wearing small shorts only. Height was measured on a Harpenden scale with $0.1-\mathrm{cm}$ precision. Pubertal development was assessed from testicular volume. The length and width of the testicles were measured with a ruler to the nearest millimeter. Testicular volume was calculated from the formula $0.52 \times$ longitudinal axis in $\mathrm{cm} \times$ (transverse axis in $\mathrm{cm})^{2}(12)$. The mean testicular volumes were used. Several cutoff points of testicular volume have been suggested to differentiate prepubertal boys from those in whom puberty has started. The suggested limits vary from 2 to $4 \mathrm{~mL}$ or approximately $20 \mathrm{~mm}(13-16)$. We arbitrarily adopted a cutoff point of $2 \mathrm{~mL}$ to draw a line between prepuberty and early puberty, although we are aware that the changes involved in puberty are gradual phenomena.

At the beginning of the study, the mean age was $11.9 \pm$ 0.05 (SEM) y (range, 11.1-13.3 y). The mean body height and weight of the boys increased from $150.5 \pm 0.9$ to $155.2 \pm 1.0 \mathrm{~cm}$ and from $41.1 \pm 1.0$ to $44.6 \pm 1.1 \mathrm{~kg}$, respectively. Because growth of testicular volume is the quantitative indicator of clinical development in male puberty, testicular volume was determined at each visit. Furthermore, we divided the boys according to the calculated testicular volumes in four categories: volumes < $2.0 \mathrm{~mL}, \geq 2.0$ but $<8 \mathrm{~mL}, \geq 8$ but $<14 \mathrm{~mL}$, and $\geq 14$ $\mathrm{mL}$ (Tables 1 and 2). Of the 60 boys, 21 had a mean testicular volume of $<2.0 \mathrm{~mL}$ and thus were considered prepubertal at the beginning of the study. The other 39 boys had pubertal testicular volumes ranging from 2.0 to $12.0 \mathrm{~mL}$. The mean testicular volume increased from 3.4 \pm 0.3 to $6.1 \pm 0.5 \mathrm{~mL}$ during the study. At the end of the study, six boys were still prepubertal (Tables 1 and 2).

Laboratory analyses. Venous blood samples were drawn between 0800 and $1400 \mathrm{~h}$. Hb concentrations were measured in the clinical laboratory with a Coulter Counter $\mathrm{T}$ 890 (Coulter Electronics, Hialeah, FL). Serum testosterone concentrations were determined by RIA in the clinical laboratory (17). Serum sex hormone-binding globulin (SHBG) concentrations were determined by fluoroimmunoassay (DELFIA; Wallac, Turku, Finland). To have a more sensitive measure of the androgen status, we also used the free androgen index, calculated as total testosterone/SHBG $\times 100(18)$.

Table 1. Mean $H b$ concentration $(g / L)$ in relation to testicular volume in 60 healthy boys at two examinations*

\begin{tabular}{crr}
\hline \multirow{2}{*}{$\begin{array}{c}\text { Testicular volume } \\
(\mathrm{mL})\end{array}$} & \multicolumn{3}{c}{ Examination } \\
\cline { 2 - 3 } & \multicolumn{2}{c}{1} \\
\hline 2.0 & $127 \pm 1.8(21)$ & $130 \pm 1.4(6)$ \\
$\geq 2.0<8.0$ & $130 \pm 1.4(35)$ & $132 \pm 1.0(37)$ \\
$\geq 8.0<14.0$ & $130 \pm 1.3(4)$ & $132 \pm 1.4(14)$ \\
$\geq 14.0<20.0$ & $129 \pm 1.0(60)$ & $142 \pm 5.5(3)$ \\
Total & & $132 \pm 0.8(60)$ \\
\hline
\end{tabular}

* Values are mean \pm SEM. Numbers of subjects are presented in parentheses.
Table 2. Mean IGF-I and IGFBP-3 concentrations (nmol/L) in relation to testicular volume in 60 healthy boys at two examinations

\begin{tabular}{llrr}
\hline \multirow{2}{*}{$\begin{array}{c}\text { Testicular } \\
\text { volume }(\mathrm{mL})\end{array}$} & & \multicolumn{2}{c}{ Examination } \\
\cline { 2 - 4 }$<2.0$ & IGF-I & $28.0 \pm 1.5(18)$ & $27.2 \pm 3.3(6)$ \\
& IGFBP-3 & $5.2 \pm 0.2(21)$ & $6.1 \pm 0.4(6)$ \\
$\geq 2.0<8.0$ & IGF-I & $33.3 \pm 1.4(32)$ & $28.2 \pm 1.5(37)$ \\
& IGFBP-3 & $5.4 \pm 0.2(35)$ & $5.7 \pm 0.2(37)$ \\
$\geq 8.0<14.0$ & IGF-I & $44.7 \pm 6.0(3)$ & $35.8 \pm 2.8(13)$ \\
& IGFBP-3 & $6.9 \pm 0.3(4)$ & $6.2 \pm 0.3(14)$ \\
$\geq 14.0<20.0$ & IGF-I & & $42.4 \pm 7.7(3)$ \\
& IGFBP-3 & & $7.4 \pm 0.8(3)$ \\
Total & IGF-I & $32.0 \pm 1.1(53)$ & $30.5 \pm 1.3(59)$ \\
& IGFBP-3 & $5.5 \pm 0.1(60)$ & $5.9 \pm 0.1(60)$ \\
\hline
\end{tabular}

* Values are mean \pm SEM. Numbers of subjects are presented in parentheses.

Serum IGF-I concentrations were measured from serum samples using RIA kits from INCSTAR Corp. (Stillwater, MN). The assay uses acid treatment and octadecasilylsilica extraction to dissociate IGF-I from its binding proteins. Thus, the assay measures the total IGF-I in serum. The sensitivity was $2.0 \mathrm{nmol} / \mathrm{L}$, the intraassay variation was $10 \%$ at the level of $13 \mathrm{nmol} / \mathrm{L}$, and the recoveries by this extraction method are $81-106 \%$ according to the manufacturer. After octadecasilyl-silica treatment, only $2.8 \pm$ $0.54 \%(n=9)$ of IGFBP-3 remained in the extract.

Serum IGFBP-3 concentrations were measured from diluted serum samples by a two-site immunofluorometric assay (19), using MAb generated against recombinant IGFBP-3 ${ }^{\text {E.coli }}$. The assay used MAb F42-1B6 in the solid phase and MAb F41-5C11 as the Eu-labeled tracer. The measurement range covered $0.6-650 \mu \mathrm{g} / \mathrm{L}$. The intraassay variation was $3.6-6.2 \%$ and the interassay variation $5.4-11 \%$. The assay had no cross-reaction with other human IGFBP (IGFBP-1, -2, -4, -5, and -6) or with IGF-I.

Statistical analyses. We used logarithmic transformation of serum testosterone concentrations, because the distribution was skewed. All the other values were normally distributed, and they were expressed as mean \pm SEM. For statistical analyses, we used simple and multiple regression analyses and the paired $t$ test. The number of subjects was 60 for all but the IGF-I values, which were obtained from 53 boys at the first examination and 59 at the second.

\section{RESULTS}

During the study period of $9 \mathrm{mo}$, the mean $\mathrm{Hb}$ concentration increased from $129 \pm 1.0$ to $132 \pm 0.8 \mathrm{~g} / \mathrm{L}(p=$ 0.002 ; Table 1). The mean concentration of serum IGF-I was $32.0 \pm 1.1 \mathrm{nmol} / \mathrm{L}$ at the first and $30.5 \pm 1.3 \mathrm{nmol} / \mathrm{L}$ at the second examination (Table 2). A positive correlation was observed between the serum concentration of IGF-I and the blood concentration of $\mathrm{Hb}$ at the first examination only $(r=0.36, p=0.008$; Fig. 1$)$. The mean serum concentration of IGFBP-3 was $5.5 \pm 1.2 \mathrm{mg} / \mathrm{L}$ at the first and $5.9 \pm 1.3 \mathrm{mg} / \mathrm{L}$ at the second examination $(p$ $<0.001$; Table 2). A positive correlation was observed 




Figure 1. Blood $\mathrm{Hb}$ concentration in relation to serum IGF-I (upper graphs) and IGFBP-3 concentrations (lower graphs) in healthy boys measured with a 9-mo interval.

between the concentrations of IGFBP-3 and $\mathrm{Hb}$ at both examinations $(r=0.53, p<0.001$, and $r=0.39, p=$ 0.003; Fig. 1).

The levels of IGF-I and IGFBP-3 correlated positively with each other at both examinations $(r=0.51$ and 0.67 , $p<0.001)$. Positive correlations were also observed between the serum concentrations of IGF-I or IGFBP-3 and the different criteria of growth and pubertal development (Table 3). The correlations were more significant at the second examination than at the first.

Table 3. Correlation coefficients and p values of correlations between serum IGF-I and IGFBP-3 concentrations and various criteria of growth and pubertal development

\begin{tabular}{|c|c|c|c|c|}
\hline & \multicolumn{2}{|c|}{ Serum IGFBP-3 } & \multicolumn{2}{|c|}{ Serum IGF-I } \\
\hline & Exam 1 & Exam 2 & Exam 1 & Exam 2 \\
\hline \multicolumn{5}{|c|}{ Body height } \\
\hline$r$ & 0.31 & 0.48 & 0.14 & 0.33 \\
\hline$p$ & 0.02 & $<0.001$ & 0.34 & 0.01 \\
\hline \multicolumn{5}{|c|}{ Height velocity } \\
\hline$r$ & 0.05 & 0.56 & 0.27 & 0.57 \\
\hline$p$ & 0.68 & $<0.001$ & 0.047 & $<0.001$ \\
\hline \multicolumn{5}{|c|}{ Body weight } \\
\hline$r$ & 0.36 & 0.48 & 0.23 & 0.43 \\
\hline$p$ & 0.005 & $<0.001$ & 0.11 & $<0.001$ \\
\hline \multicolumn{5}{|c|}{ Testicular volume } \\
\hline$r$ & 0.38 & 0.48 & 0.38 & 0.47 \\
\hline$p$ & 0.003 & $<0.001$ & 0.005 & $<0.001$ \\
\hline \multicolumn{5}{|c|}{ Log serum testosterone } \\
\hline$r$ & 0.31 & 0.36 & 0.47 & 0.44 \\
\hline$p$ & 0.02 & 0.005 & $<0.001$ & $<0.001$ \\
\hline \multicolumn{5}{|c|}{ Free androgen index } \\
\hline$r$ & 0.15 & 0.39 & 0.41 & 0.45 \\
\hline$p$ & 0.25 & 0.004 & 0.003 & $<0.001$ \\
\hline
\end{tabular}

The mean concentration of serum testosterone increased from $1.2 \pm 0.2$ to $3.2 \pm 0.5 \mathrm{nmol} / \mathrm{L}(p<0.001)$. No associations were observed between testosterone and $\mathrm{Hb}$ levels (Fig. 2). However, positive correlations were found between the serum concentrations of testosterone and those of IGF-I $(r=0.47, p<0.001$, and $r=0.44, p$ $<0.001)$ and of IGFBP-3 $(r=0.31, p=0.018$, and $r=$ $0.36, p=0.005$; Table 3 ).

Multiple linear regression analysis showed that, of the factors studied including IGF-I, IGFBP-3, testosterone, and testicular volume, only IGFBP-3 was independently associated with the $\mathrm{Hb}$. The analysis indicates an increase of $3.8 \mathrm{~g} / \mathrm{L}(95 \%$ confidence limits, $1.3-6.3 \mathrm{~g} / \mathrm{L} ; p=$ $0.004)$ in $\mathrm{Hb}$ concentration per $1 \mathrm{U}$ of IGFBP-3 at the first examination and $2.5 \mathrm{~g} / \mathrm{L}$ (95\% confidence limits, $0.4-4.7$ $\mathrm{g} / \mathrm{L} ; p=0.02$ ) at the second. The results of these analyses remained of similar magnitude when the total testosterone values were replaced by the free androgen indexes.

\section{DISCUSSION}

Our observation shows that, in healthy prepubertal and early pubertal boys, $\mathrm{Hb}$ concentration is correlated to IGFBP-3 concentration and less significantly to serum IGF-I. These findings indicate indirectly that growth hormone may be involved in the regulation of physiologic $\mathrm{Hb}$ concentration.

Earlier in vitro studies (3, 4, 6-9) lend support to speculations that the associations we observed indicate a causal relationship. In human cell cultures $(6,7)$ and in animal experiments $(3-5,8,9)$, IGF-I stimulates erythropoietic colony and burst formations. In vivo, the mechanism is likely to be more complex because of the presence of multiple regulators of growth and pubertal development. Wilson et al. (20) observed that pubertal stage was significantly associated with IGFBP-3 in girls. They noticed a small but significant association between IGFBP-3 and $\mathrm{Hb}$ concentrations but did not discuss this observation.

In the study of Thomsen et al. (11), the physiologic rise in $\mathrm{Hb}$ concentration was related to testosterone secretion in pubertal boys. However, in that study, despite elevated testosterone levels at early puberty, the increase in $\mathrm{Hb}$ concentration took place later. In our study, we

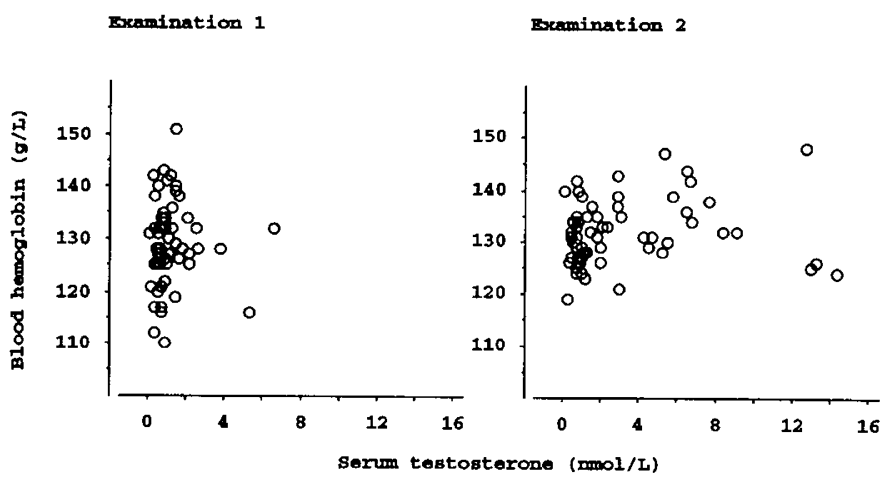

Figure 2. Blood $\mathrm{Hb}$ concentration in relation to serum testosterone in healthy boys measured with a 9-mo interval. 
observed no association between testosterone and $\mathrm{Hb}$ concentrations, although both $\mathrm{Hb}$ and testosterone levels had already increased significantly. A recent study shows that testosterone increases serum IGF-I levels in normal men (21). It is possible that the effects of testosterone on $\mathrm{Hb}$ levels are mediated via increased IFGF-I levels also in children, reflected in elevated serum IGFBP-3 levels as seen in this study. According to our findings, the IGF-I and IGFBP-3 correlated with the $\mathrm{Hb}$ level already in early puberty. These findings indicate that the role of androgens and other regulators of erythropoiesis may be different at different stages of puberty.

It may be argued that the positive correlations between $\mathrm{Hb}$ and IGF-I or IGFBP-3 concentrations are merely coincidental changes occurring during puberty without any causal relationship. Although this may be the case, our results show that, as in adult men (21), serum testosterone concentrations correlate positively with IGF-I and IGFBP-3 levels in children but not with the $\mathrm{Hb}$ concentration. Our results indicate that testosterone may not be the direct stimulator of erythropoiesis, but mediators of growth hormone action may play a role in the determination of the individual's $\mathrm{Hb}$ concentration in early puberty.

Acknowledgment. The authors thank Celtrix Pharmaceuticals, Santa Clara, CA, for recombinant IGFBP-3 used for generation of monoclonal anti-IGFBP-3 antibodies.

\section{REFERENCES}

1. Daughaday WH, Rotwein P 1989 Insulin-like growth factors I and II. Peptide, messenger ribonucleic acid and gene structures, serum, and tissue concentrations. Endocr Rev 10:68-91

2. Blum WF 1992 Insulin-like growth factors and their binding proteins. In: Ranke MB (ed) Functional Endocrinologic Diagnostics in Children and Adolescents. J \& J Verlag, Mannheim, Germany, pp 102-107
3. Aron DC 1992 Insulin-like growth factor I and erythropoiesis. Biofactors 3:211-216

4. Kurtz A, Härtl W, Jelkmann W, Zapf J, Bauer C 1985 Activity in fetal bovine serum that stimulates erythroid colony formation in fetal mouse livers is insulinlike growth factor I. J Clin Invest 76:1643-1648

5. Kurtz A, Matter R, Eckardt KU, Zapf J 1990 Erythropoiesis, serum erythropoietin, and serum IGF-I in rats during accelerated growth. Acta Endocrinol 122:323-328

6. Claustres M, Chatelain P, Sultan C 1987 Insulin-like growth factor I stimulates human erythroid colony formation in vitro. J Clin Endocrinol Metab 65:78-82

7. Sanders M, Sorba S, Dainiak N 1993 Insulin-like growth factors stimulate erythropoiesis in serum-substituted umbilical cord blood cultures. Exp Hematol 21:25-30

8. Boyer SH, Bishop TR, Rogers OC, Noyes AN, Frelin LP, Hobbs S 1992 Roles of erythropoietin, insulin-like growth factor I, and unidentified serum factors in promoting maturation of purified murine erythroid colony-forming units. Blood 80:2503-2512

9. Muta K, Krantz SP 1993 Apoptosis of human erythroid colony-forming cells is decreased by stem cell factor and insulin-like growth factor I as well as erythropoietin. J Cell Physiol 156:264-271

10. Shahidi NT 1973 Androgens and erythropoiesis. N Engl J Med 289:72-80

11. Thomsen K, Riis B, Krabbe S, Christiansen C 1986 Testosterone regulates the haemoglobin concentration in male puberty. Acta Paediatr Scand 75:793796

12. From Hansen P, With TK 1952 Clinical measurements of testes. Acta Med Scand Suppl 206:457-465

13. Tanner JM, Whitehouse RH 1976 Clinical longitudinal standards for height, weight, height velocity, weight velocity, and stages of puberty. Arch Dis Child 51:170-179

14. Knorr D, Bidlingmaier F, Butenandt O, Fendel H, Ehrt-Wehle R 1974 Plasma testosterone in male puberty. Acta Endocrinol 75:181-194

15. Chapman AJ 1985 Delayed puberty. BMJ 290:1493-1496

16. Karlberg P, Taranger J, Engström I, Lichtenstein H, Svennberg-Redegren I 1976 Somatic pubertal development. Acta Paediatr Scand Suppl 258:121-135

17. Apter D, Jänne O, Karvonen P, Vihko R 1976 Simultaneous determination of five sex hormones in human serum by radioimmunoassay after chromatography on Lipidex-5000. Clin Chem 22:32-38

18. Selby C 1990 Sex hormone binding globulin: origin, function and clinical significance. Ann Clin Biochem 27:532-541

19. Koistinen H, Seppälä M, Koistinen R 1994 Different forms of insulin-like growth factor-binding protein-3 detected in serum and seminal plasma. Clin Chem 40:531-536

20. Wilson DM, Stene MA, Killen JD, Hammer LD, Litt IF, Hayward C 1992 Insulin-like growth factor binding protein-3 in normal pubertal girls. Acta Endocrinol 126:381-386

21. Hobbs CJ, Plymate SR, Rosen CJ, Adler RA 1993 Testosterone administration increases insulin-like growth factor-I levels in normal men. J Clin Endocrinol Metab 77:776-779 